\title{
Synthesis and SAR evaluation of coumarin derivatives as potent cannabinoid receptor agonists
}

\author{
Florian Mohr $^{\text {a, b, } 1}$, Thomas Hurrle ${ }^{\text {a, c }}$, Lindsey Burggraaff ${ }^{\text {b, }}{ }^{2}$, Lukas Langer $^{\text {a, }}{ }^{2}$, \\ Martijn P. Bemelmans ${ }^{b}$, Maximilian Knab ${ }^{a}$, Martin Nieger ${ }^{d}$, Gerard J.P. van Westen ${ }^{b}$, \\ Laura H. Heitman ${ }^{\text {b, ** }}$, Stefan Bräse ${ }^{\text {a, c, * }}$ \\ ${ }^{a}$ Institute of Organic Chemistry, Karlsruhe Institute of Technology (KIT), Fritz-Haber-Weg 6, D-76131, Karlsruhe, Germany \\ ${ }^{\mathrm{b}}$ Division of Drug Discovery and Safety, Leiden Academic Centre for Drug Research, Leiden University, Einsteinweg 55, 2333CC, Leiden, the Netherlands \\ ${ }^{\mathrm{c}}$ Institute of Biological and Chemical Systems - Functional Molecular Systems, Karlsruhe Institute of Technology (KIT), Hermann-von-Helmholtz-Platz 1, D- \\ 76344, Eggenstein-Leopoldshafen, Germany \\ ${ }^{\mathrm{d}}$ Department of Chemistry, University of Helsinki, P.O. Box 55 (A. I. Virtasen Aukio 1), 00014, Finland
}

\section{A R T I C L E I N F O}

\section{Article history:}

Received 6 October 2020

Received in revised form

1 March 2021

Accepted 1 March 2021

Available online 7 April 2021

\section{Keywords:}

$\mathrm{CB}$ receptors

Synthetic cannabinoids

Coumarins

$\mathrm{CB}_{2}$ agonists

Endocannabinoid system

Radioligand binding assays

\begin{abstract}
A B S T R A C T
We report the development and extensive structure-activity relationship evaluation of a series of modified coumarins as cannabinoid receptor ligands. In radioligand, and $\left.{ }^{35} \mathrm{~S}\right] \mathrm{GTP} \gamma \mathrm{S}$ binding assays the $\mathrm{CB}$ receptor binding affinities and efficacies of the new ligands were determined. Furthermore, we used a ligand-based docking approach to validate the empirical observed results. In conclusion, several crucial structural requirements were identified. The most potent coumarins like 3-butyl-7-(1-butylcyclopentyl)5-hydroxy-2H-chromen-2-one (36b, $K_{\mathrm{i}} \mathrm{CB}_{2} 13.7$ nM, EC $5018 \mathrm{nM}$ ), 7-(1-butylcyclohexyl)-5-hydroxy-3propyl-2H-chromen-2-one $\left(\mathbf{3 9 b}, K_{\mathrm{i}} \mathrm{CB}_{2} 6.5 \mathrm{nM}, \mathrm{EC}_{50} 4.51 \mathrm{nM}\right)$ showed a $\mathrm{CB}_{2}$ selective agonistic profile with low nanomolar affinities.
\end{abstract}

๑) 2021 Published by Elsevier Masson SAS.

\section{Introduction}

The cannabinoid receptor 1 and $2\left(\mathrm{CB}_{1}\right.$ and $\left.\mathrm{CB}_{2}\right)$ subtypes belong to the rhodopsin-like class $\mathrm{A}$ of $\mathrm{G}$-protein coupled receptors (GPCRs) [1,2]. They represent the central regulatory units of the endocannabinoid system (ECS) and the target structures of the two endocannabinoids anandamide and 2-arachidonoylglycerol. The ECS refers to a ubiquitous, complex lipid-based (neuro-) transmitter system, which is involved in numerous essential physiological and pathological processes such as food intake, mood, energy balance, pain, anxiety, (neuro-) inflammation, immune

\footnotetext{
* Corresponding author. Institute of Organic Chemistry, Karlsruhe Institute of Technology (KIT), Fritz-Haber-Weg 6, D-76131, Karlsruhe, Germany.

** Corresponding author.

E-mail addresses: 1.h.heitman@chem.leidenuniv.nl (L.H. Heitman), braese@kit. edu (S. Bräse).

1 Present Addresses: New address of Florian Mohr: Eberhard Karls Universität Tübingen, Auf der Morgenstelle 8, 72076 Tübingen, Germany.

2 These authors contributed equally.
}

function, metabolic regulations, neuronal plasticity or reproduction [3-14]. In recent decades numerous synthetic CB ligands were developed by academic labs or pharmaceutical companies to investigate the influence of the ECS on a wide range of diseases or disorders. In several studies, some synthetic CB ligands exhibited neuroprotective properties like anti-inflammatory effects or pain relief. Furthermore, they showed cardioprotective effects associated with stroke or heart failures, positive results treating osteoporosis or arteriosclerosis, and anticancer agents inhibiting tumor growth $[15,16]$.

In previous studies, we already demonstrated cannabinergic activities for substituted 3-benzylcoumarins [17,18]. The huge potential of 3-benzylcoumarins as lead structures for the development of CB ligands can be highlighted by structural comparison with established classical and non-classical CB ligands (Fig. 1). In general, long lipophilic alkyl chains at position 7 were identified as crucial for any $\mathrm{CB}$ receptor activity which can be further increased by the introduction of branched alkyl chains at this position. $\mathrm{CB}$ receptor subtype selectivity was achieved either by a methoxy or a 


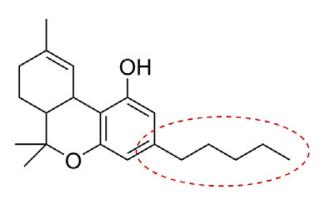

$\Delta-9-\mathrm{THC}, 1$

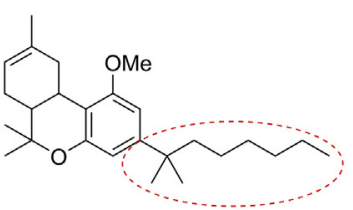

L-759633, 2
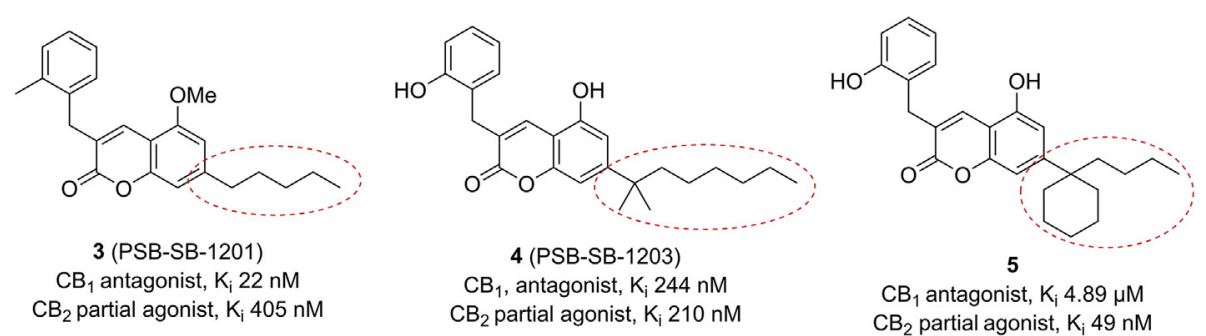

$\mathrm{CB}_{2}$ partial agonist, $\mathrm{K}_{\mathrm{i}} 49 \mathrm{nM}$

Fig. 1. Structural comparison of our first-generation 3-benzylcoumarins (3-5) with the nonselective CB agonist $\Delta^{9}$-THC (1) and the selective $\mathrm{CB}_{2}$ agonist L-759633 (2).

hydroxy group at position 5 , whereas last was more selective towards the $\mathrm{CB}_{2}$ receptor Fig. 1 .

In the presented study we report the results of our secondgeneration coumarin-based $\mathrm{CB}$ ligands. In this generation, we focused on the substitution of the 3-benzyl group with other nonpolar substituents leading to several new ligands with strongly increased potency, high $\mathrm{CB}_{2}$ selectivity, and efficacies from full to partial agonistic.

\section{Results and discussion}

Structural Consideration. In previous studies, we reported the development of substituted coumarins as novel CB or GPR55 receptor ligands [17-19]. The most potent coumarin derivatives of the studies and their structural characteristics compared to classical phytocannabinoid $\delta^{9}$-THC and the selective $\mathrm{CB}_{2}$ agonist L759633 are depicted in Fig. 1 [20]. As our previous studies mainly investigated the SARs of lipophilic substituents at position 7 (3-5), in this study we focused on substituting the benzyl moiety at position 3 with other lipophilic substituents to improve affinity and selectivity of our coumarin derivatives. Furthermore, based on the potentially high potency of the 1,1-dimethylalkyl moiety at position 7 (4, see Ref. [18]), we synthesized an additional series of coumarin derivatives (7a-23b), to further investigate the structural influence of this moiety.

Syntheses. All 3-benzyl- and pyridinyl coumarins 7a-32a were synthesized from the respective substituted salicylic aldehydes and $\alpha, \beta$-unsaturated aldehyde, using an NHC catalyzed, microwave supported umpoled domino reaction $\left(110{ }^{\circ} \mathrm{C}, 50 \mathrm{~min}\right)$ as previously described (Scheme 1A) [17,21,22]. The respective 3-alkylcoumarins 33a-41a were synthesized from the appropriately substituted salicylic aldehyde in the presence of potassium carbonate and suspended in the respective acid anhydride under microwave irradiation $\left(180^{\circ} \mathrm{C}, 65 \mathrm{~min}\right)$ as previously described (Scheme 1A) [23]. 3-Phenylcouamrins 43a-52a were synthesized by Suzukicoupling of the brominated coumarin derivative $\mathbf{4 2}$ (Scheme 1B). Phenolic coumarin derivatives $\mathbf{7 b - 5 2 b}$ were synthesized by cleavage of the methyl ether bond in the presence of boron tribromide in dichloromethane at $-78^{\circ} \mathrm{C}$ according to a literature procedure [18]. The products were purified by flash column chromatography or filtration over a small silica pad Scheme 1.

Biology. The receptor affinities of the coumarin-derivatives 7a52b were determined in a radioligand displacement assay on Chinese hamster ovary $(\mathrm{CHO})$ membrane fractions overexpressing the human cannabinoid receptor $\mathrm{CB}_{1}$ or $\mathrm{CB}_{2}$ and $\left[{ }^{3} \mathrm{H}\right] \mathrm{CP} 55,940$ as $\mathrm{CB}$ receptor radioligand. Initially, the coumarin derivatives were tested at a concentration of $1 \mu \mathrm{M}$. Full concentration-inhibition curves for determination of $K_{\mathrm{i}}$ values were performed, if radioligand displacement exceeded $50 \%$ at $1 \mu \mathrm{M}$. The results are reported in Table 1 and Supporting Information Table S1. Functional activities were determined in an in vitro $\left[{ }^{35} \mathrm{~S}\right] \mathrm{GTP} \gamma \mathrm{S}$ binding assay on $\mathrm{CHO}$ membrane fractions overexpressing the human cannabinoid receptor $\mathrm{CB}_{1}$ or $\mathrm{CB}_{2}$. The efficacies ( $\mathrm{E}_{\max }$ ) of tested compounds $(1 \mu \mathrm{M})$ were determined relative to the maximal response of reference full

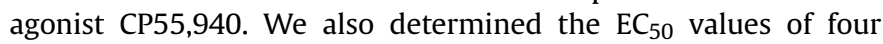
representative agonists relative to the reference full agonist CP55,940. These results are shown in Table 2 and Supporting Information Figs. S1 and S2.

Structure-Activity Relationships (SARs). The coumarinderivatives included in this study were substituted with a large variety of substituents at position 3,5 , and 7 , ranging from small ( $\mathrm{H}$, methyl, ethyl, and propyl) to large (butyl, pentyl, hexyl, phenyl, benzyl, pyridinyl) or bulky substituents (tert-butyl, 1butylcyclopentyl, 1-butylcyclohexyl, 1,1-dimethylpentyl, 1,1dimethylheptyl) and can be divided into four groups of individual substituents: the first group consists of 3-benzylcoumarins with a 1,1-dimethylalkyl side chain at position 7 (7a-23b). In the second group, 3-pyridinylmethyl substituents were introduced to the coumarin core $(\mathbf{2 4 a}-\mathbf{3 2 b})$. The third group is characterized by 3-alkyl substituents (33a-41b) and the fourth group by 3-phenyl residues (43a-52b). Position 5 was either substituted with a methoxy or hydroxy group. At the 3-aryl residues further modifications (methyl, methoxy, or hydroxy), which had been beneficial for the $C B$ receptor affinity in our previous studies, as well as new fluorinated substituents ( $\mathrm{F}$ or trifluoromethyl) were introduced. Observed affinities are depicted in Table 1 (for full data see Supporting Information Table S1). Selected full concentrationinhibition curves for the most potent and most selective coumarin derivatives are depicted in Fig. 2 Figs1.

In the first group, the additional series of coumarin derivatives bearing a $7-\left(1,1^{\prime}\right.$-dimethylalkyl) moiety, small (methyl), medium (butyl), or large (hexyl) alkyl chains next to the 1,1-dimethylalkyl group were tested. As expected, a critical length for any affinity (13a, containing a butyl group; $K_{\mathrm{i}} \mathrm{CB}_{1}: 486 \mathrm{nM}, \mathrm{CB}_{2}:>1 \mu \mathrm{M}$ ) was observed. Simultaneously no (13a; $\left.K_{\mathrm{i}} \mathrm{CB}_{1}: 486 \mathrm{nM}, \mathrm{CB}_{2}:>1 \mu \mathrm{M}\right)$ or only small (14a, o-methyl, $K_{\mathrm{i}} \mathrm{CB}_{1}: 217 \mathrm{nM}, \mathrm{CB}_{2}: \gg 1 \mu \mathrm{M}$; 15a, $o$ methoxy, $K_{\mathrm{i}} \mathrm{CB}_{1}$ : $196 \mathrm{nM}, \mathrm{CB}_{2}: 231 \mathrm{nM}$ ) substituents on the 3benzyl ring were tolerated. $\mathrm{CB}$ receptor selectivity was strongly 
A<smiles>[R]c1cc(O)c(C=O)c(OC)c1</smiles><smiles>[R]c1cc(OC)c2cc([R])c(=O)oc2c1</smiles><smiles>[R]c1cc(O)c2cc([R])c(=O)oc2c1</smiles>

6a-f

$7 a-41 a$

$7 b-40 b$<smiles>[R]c1cc(O)c2cc(-c3ccc([R])c(-c4ccc(C(C)C)c(O)c4)c3)c(=O)oc2c1</smiles>

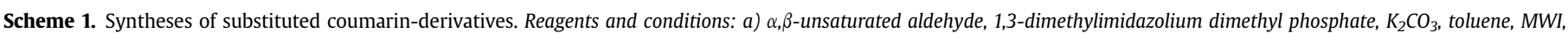

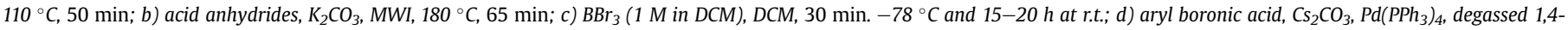
dioxane, $90^{\circ} \mathrm{C}, 16 \mathrm{~h}$.

influenced by the substitution of position 5, whereby a methoxy group showed higher selectivity at $\mathrm{CB}_{1}$ and a more polar hydroxy group at $\mathrm{CB}_{2}$ (e.g. 22b, 4.5 fold).

In the next group, the 3-benzyl group was changed to the heteroaromatic 3-pyridinylmethyl group, and the derivatives contained either large (pentyl) or bulky (1-butylcylcoalkyl) groups at position 7. In all tested derivatives a free 5-hydroxy group drastically decreased receptor affinities for $\mathrm{CB}_{1}$ and $\mathrm{CB}_{2}$ (except $\mathbf{2 8 b}$, 30b, and 32b). Derivatives with a large pentyl group at position 7 showed high affinities at low nanomolar levels on both receptors (e.g. 24a, $K_{\mathrm{i}} \mathrm{CB}_{1}$ : $70.3 \mathrm{nM}, \mathrm{CB}_{2}$ : $82.4 \mathrm{nM}$ and 25a, $K_{\mathrm{i}} \mathrm{CB}_{1}$ : $171 \mathrm{nM}$, $\mathrm{CB}_{2}$ : $56.5 \mathrm{nM}$ ), whereas bulky substituents showed high selectivity towards the $\mathrm{CB}_{2}$ receptor (e.g. 30b, $K_{\mathrm{i}} \mathrm{CB}_{1}: \ll 1 \mu \mathrm{M}, \mathrm{CB}_{2}: 71.9 \mathrm{nM}$ ). Within this group, the pyridyl configuration strongly contributed to the receptor affinities (compare 24a, 25a, and 26a). At the $C_{1}$ receptor highest potency was observed for 0 -pyridyl (24a) over $m$ pyridyl (25a), to a complete loss of potency for $p$-pyridyl (26a). Contrary to that, at the $\mathrm{CB}_{2}$ receptor the order of potencies was $m$ pyridyl (25a) $>0$-pyridyl (24a) $\gg p$-pyridyl (26a).

Therefore, as the next step in the study, the bulky substituents at position 7 were combined with highly flexible aliphatic chains (from methyl to butyl) at position 3. In contrast to previous observations in the group before, a free hydroxy group at position 5 was highly favorable and thereby resulted in the derivatives with the highest potencies (e.g. 36b, $K_{\mathrm{i}} \mathrm{CB}_{1}: \sim 1 \mu \mathrm{M}, \mathrm{CB}_{2}: 13.7 \mathrm{nM}$ and 39b, $K_{\mathrm{i}} \mathrm{CB}_{1}$ : $159 \mathrm{nM}, \mathrm{CB}_{2}: 6.5 \mathrm{nM}$ ) and selectivity (e.g. 40b $\mathrm{CB}_{2} / \mathrm{CB}_{1}$ $\sim 79$-fold) of this study. Not surprisingly, nearly all derivatives (only exception 39b) with the polar 5-hydroxy group showed no or low $(\sim 1 \mu \mathrm{M})$ affinity at the $\mathrm{CB}_{1}$ receptor. However, at the $\mathrm{CB}_{2}$ receptor, an influence of the cycloalkyl ring size on the optimal alkyl chain length was observed. For the 7-(1-butylcyclopentyl) a steady increase in potency from a very low affinity for the methylsubstituted (33a, $K_{\mathrm{i}} \mathrm{CB}_{2}: \sim 1 \mu \mathrm{M}$ ), up to a very high affinity if butyl substituted (36b, $K_{\mathrm{i}} \mathrm{CB}_{2}$ : $13.7 \mathrm{nM}$ ) was found. Increasing the cycloalkyl ring size to hexyl reduced the optimal length of the 3alkyl chain by one carbon to the propyl substituent (compare 35b and $36 \mathrm{~b}-39 \mathrm{~b}$ and $\mathbf{4 0 b}$ ).

Lastly, the exchange of the substituent at the 3-position to a phenyl group (group 4) abolished the high affinities at both CB receptors completely, indicating structural flexibility at the 3position as crucial for high receptor bindings.

Functional properties. For the most potent coumarin derivatives $\left[{ }^{35} \mathrm{~S}\right] \mathrm{GTP} \gamma \mathrm{S}$ binding assays were conducted, to investigate their intrinsic activities after receptor binding. In our previous studies the full range of efficacies from antagonist or inverse agonists, as well as partial or full agonists were observed [17-19].
Initially, the efficacies $\left(E_{\max }\right)$ were determined with a final ligand concentration of $1 \mu \mathrm{M}$ and compared to the maximum response of full agonist CP55,940 (1 $\mu \mathrm{M}$, set at 100\%). Additionally, four representative ligands were chosen, and full concentration-response curves were measured to determine $\mathrm{EC}_{50}$ values. The results are shown in Table 2.

All tested coumarin derivatives, independently of receptor selectivity, showed agonistic activities. The cyclopentyl substituted coumarins (28b, 34b-36b) were identified to behave like a full agonist, whereas the remaining (24a, 25a, 37b-40b) showed partial agonistic efficacies. The dual $\mathrm{CB}_{1} / \mathrm{CB}_{2}$ active coumarin derivatives (24a, 25a, and 39b) showed at $C_{1}$ a partial agonistic activity with low $\mathrm{EC}_{50}$ values at $\mu \mathrm{M}$ level. However, at $\mathrm{CB}_{2}$ drastically higher efficacies up to low $\mathrm{nM}$ levels (e.g. 39b) were determined.

Moreover, also at the $\mathrm{CB}_{2}$ receptor for the cyclopentyl substituted coumarins (28b, 34b-36b) we observed a much higher functional selectivity than receptor subtype-specific potency. This observation can be explained by a better localization inside the active pocket during the transition of the GPCR from the resting into the active state. Thereby a minimum of flexibility between the transmembrane (TM) segments is needed to reach the active state. Unsubstituted or cyclohexyl substituted coumarins are either too week to stabilize the transformation or too big and reducing the necessary flexibility of the TM segments too much.

Computational ligand-receptor docking studies. Additionally to the SAR study, we performed an in-silico docking study to analyze substitution-dependent binding behavior. Crystal structures of the receptor subtypes and their co-crystallized ligands (PDB CB 1 : 5XRA [24] and $\mathrm{CB}_{2}$ : 5ZTY [25]) were used for docking, in which the co-crystalized ligand was used as a binding pocket reference. All the tested coumarins were docked into both receptor subtypes without including any constraints regarding binding preference and affinity. As the used crystal structure of the $\mathrm{CB}_{1}$ receptor refers to an active state of the receptor population, several key regions were identified, which were crucial for high receptor binding (Fig. 3). For the $\mathrm{CB}_{2}$ receptor no crystal structure in an active state was available yet, thus clear and rational docking poses for the presented agonistic coumarin derivatives could not be obtained Figs 2 - s7.

In the receptor-binding site of the $\mathrm{CB}_{1}$ receptor, three important regions were identified to have the most significant impact for a high coumarin binding affinity (Fig. 3, circles). A hydrophobic pocket at the upper end (blue circle) of the binding site, mainly encompassed by the amino acid (AA) residues $F 177^{2.64}$ and $\mathrm{F} 189^{3.25}$, another second hydrophobic pocket at the lower end (black circle), 
Table 1

Potencies of coumarin derivatives on the CB receptor subtypes.

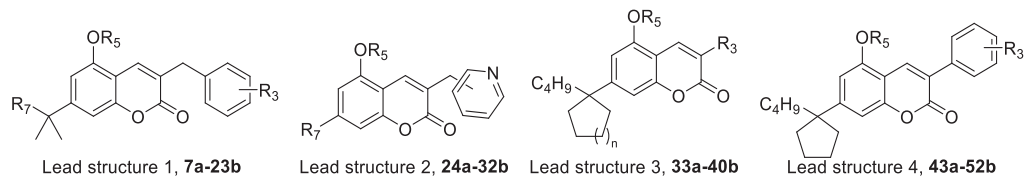

\begin{tabular}{|c|c|c|c|c|c|}
\hline \multirow[t]{2}{*}{$\mathrm{cmp}$} & \multirow[t]{2}{*}{$\mathrm{R}^{3}$} & \multirow[t]{2}{*}{$\mathrm{R}^{5}$} & \multirow[t]{2}{*}{$\mathrm{R}^{7}$} & $\mathrm{hCB}_{1}$ & $\mathrm{hCB}_{2}$ \\
\hline & & & & \multicolumn{2}{|c|}{ 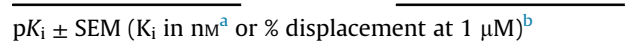 } \\
\hline \multicolumn{6}{|c|}{ Group 1: 7-(1,1-dimethylakyl)-3-benzylcoumarins } \\
\hline $13 a$ & $\mathrm{H}$ & methoxy & butyl & $6.31 \pm 0.22(486)$ & $<6.00(39 \%)$ \\
\hline $13 b$ & $\mathrm{H}$ & hydroxy & butyl & $<6.00(12 \%)$ & $<6.00(24 \%)$ \\
\hline $14 \mathrm{a}$ & $o$-methyl & methoxy & butyl & $6.66 \pm 0.15(217)$ & $<6.00(32 \%)$ \\
\hline $14 \mathrm{~b}$ & $o$-methyl & hydroxy & butyl & $<6.00(30 \%)$ & $<6.00(41 \%)$ \\
\hline $15 a$ & o-methoxy & methoxy & butyl & $6.71 \pm 0.11(196)$ & $6.64 \pm 0.003(231)$ \\
\hline $15 b$ & o-hydroxy & hydroxy & butyl & $<6.00(24 \%)$ & $<6.00(37 \%)$ \\
\hline $53 a$ & $\mathrm{H}$ & methoxy & hexyl & $1.43 \pm 0.49^{\mathrm{d}, ~[}[18]^{]}$ & $4.12 \pm 0.31^{\mathrm{d},[}[18]^{]}$ \\
\hline $53 b$ & $\mathrm{H}$ & hydroxy & hexyl & $2.63 \pm 1.23^{\mathrm{d},[}[18]^{]}$ & $0.465 \pm 0.024^{\mathrm{d},}\left[{ }^{[}[18]^{]}\right.$ \\
\hline $19 b$ & $o$-methyl & hydroxy & hexyl & $<6.00(47 \%)$ & $6.65 \pm 0.08(222)$ \\
\hline $54 a$ & o-methoxy & methoxy & hexyl & $1.02 \pm 0.38^{\mathrm{d},[}[18]^{]}$ & $3.01 \pm 4.81^{\mathrm{d},[}[18]^{]}$ \\
\hline $54 \mathrm{~b}$ & o-hydroxy & hydroxy & hexyl & $0.244 \pm 0.051^{\mathrm{d},[}[18]^{]}$ & $0.210 \pm 0.025^{\mathrm{d},[}[18]^{]}$ \\
\hline $23 a$ & $o-\mathrm{CF}_{3}$ & methoxy & hexyl & $<6.00(26 \%)$ & $\ll 6.00(3 \%)$ \\
\hline $23 b$ & $o-\mathrm{CF}_{3}$ & hydroxy & hexyl & $\sim 6.00(49 \%)$ & $<6.00(42 \%)$ \\
\hline \multicolumn{6}{|c|}{ Group 2: 3-pyridinylmethyl coumarins } \\
\hline $24 a$ & $o$-pyridyl & Methoxy & pentyl & $7.15 \pm 0.06(70.3)$ & $7.08 \pm 0.14(82.4)$ \\
\hline $24 b$ & $o$-pyridyl & Hydroxy & pentyl & $\ll 6.00(-15 \%)$ & $\ll 6.00(-17 \%)$ \\
\hline $25 a$ & $m$-pyridyl & Methoxy & pentyl & $6.77 \pm 0.12(171)$ & $7.25 \pm 0.04(56.5)$ \\
\hline $25 b$ & $m$-pyridyl & Hydroxy & pentyl & $\ll 6.00(-21 \%)$ & $\ll 6.00(-21 \%)$ \\
\hline $26 a$ & p-pyridyl & Methoxy & pentyl & $\ll 6.00(0 \%)$ & $<6.00(11 \%)$ \\
\hline $26 b$ & p-pyridyl & Hydroxy & pentyl & $\ll 6.00(-48 \%)$ & $\ll 6.00(-5 \%)$ \\
\hline $27 \mathrm{a}$ & $o$-pyridyl & Methoxy & 1-butylcyclopentyl & $<6.00(29 \%)$ & $<6.00(20 \%)$ \\
\hline $27 b$ & $o$-pyridyl & Hydroxy & 1-butylcyclopentyl & $<6.00(34 \%)$ & $<6.00(44 \%)$ \\
\hline $28 a$ & $m$-pyridyl & methoxy & 1-butylcyclopentyl & $<6.00(29 \%)$ & $<6.00(40 \%)$ \\
\hline $28 b$ & $m$-pyridyl & hydroxy & 1-butylcyclopentyl & $<6.00(19 \%)$ & $6.51 \pm 0.07(310)$ \\
\hline $29 a$ & p-pyridyl & methoxy & 1-butylcyclopentyl & $<6.00(28 \%)$ & $\ll 6.00(9 \%)$ \\
\hline $29 b$ & p-pyridyl & hydroxy & 1-butylcyclopentyl & $\ll 6.00(-24 \%)$ & $<6.00(21 \%)$ \\
\hline $30 a$ & 0 -pyridyl & methoxy & 1-butylcyclohexyl & $<6.00(47 \%)$ & $<6.00(12 \%)$ \\
\hline $30 b$ & $o$-pyridyl & hydroxy & 1-butylcyclohexyl & $\ll 6.00(-7 \%)$ & $7.14 \pm 0.13(71.9)$ \\
\hline $31 a$ & $m$-pyridyl & methoxy & 1-butylcyclohexyl & $\ll 6.00(6 \%)$ & $<6.00(11 \%)$ \\
\hline $32 \mathrm{a}$ & p-pyridyl & methoxy & 1-butylcyclohexyl & $<6.00(26 \%)$ & $\ll 6.00(3 \%)$ \\
\hline $32 b$ & p-pyridyl & hydroxy & 1-butylcyclohexyl & $\ll 6.00(5 \%)$ & $<6.00(46 \%)$ \\
\hline \multicolumn{6}{|c|}{ Group 3: 3-Alkylcoumarins } \\
\hline $33 a$ & methyl & methoxy & 1-butylcyclopentyl & $<6.00(16 \%)$ & $\ll 6.00(1 \%)$ \\
\hline $33 b$ & methyl & hydroxy & 1-butylcyclopentyl & $\ll 6.00(-10 \%)$ & $\sim 6.00(49 \%)$ \\
\hline $34 a$ & ethyl & methoxy & 1-butylcyclopentyl & $<6.00(33 \%)$ & $\ll 6.00(0 \%)$ \\
\hline $34 b$ & ethyl & hydroxy & 1-butylcyclopentyl & $<6.00(34 \%)$ & $7.22 \pm 0.08(60.6)$ \\
\hline $35 a$ & propyl & methoxy & 1-butylcyclopentyl & $<6.00(32 \%)$ & $<6.00(38 \%)$ \\
\hline $35 b$ & propyl & hydroxy & 1-butylcyclopentyl & $<6.00(47 \%)$ & $7.73 \pm 0.01(18.6)$ \\
\hline $36 a$ & butyl & methoxy & 1-butylcyclopentyl & $<6.00(15 \%)$ & $\ll 6.00(-1 \%)$ \\
\hline $36 b$ & butyl & hydroxy & 1-butylcyclopentyl & $\sim 6.00(50 \%)$ & $7.86 \pm 0.11(13.7)$ \\
\hline $37 a$ & methyl & methoxy & 1-butylcyclohexyl & $\ll 6.00(9 \%)$ & $\ll 6.00(-34 \%)$ \\
\hline $37 b$ & methyl & hydroxy & 1-butylcyclohexyl & $<6.00(19 \%)$ & $6.98 \pm 0.03(106)$ \\
\hline $38 a$ & ethyl & methoxy & 1-butylcyclohexyl & $\ll 6.00(6 \%)$ & $\ll 6.00(-1 \%)$ \\
\hline $38 b$ & ethyl & hydroxy & 1-butylcyclohexyl & $<6.00(39 \%)$ & $7.41 \pm 0.04(39.1)$ \\
\hline $39 a$ & propyl & methoxy & 1-butylcyclohexyl & $<6.00(18 \%)$ & $\ll 6.00(-4 \%)$ \\
\hline $39 b$ & propyl & hydroxy & 1-butylcyclohexyl & $6.80 \pm 0.22(159)$ & $8.19 \pm 0.12(6.5)$ \\
\hline $40 a$ & butyl & methoxy & 1-butylcyclohexyl & $\ll 6.00(-11 \%)$ & $\ll 6.00(2 \%)$ \\
\hline $40 \mathrm{~b}$ & butyl & hydroxy & 1-butylcyclohexyl & $<6.00(48 \%)$ & $7.90 \pm 0.03(12.5)$ \\
\hline \multicolumn{6}{|c|}{ Group 4: 3-Phenylcoumarins } \\
\hline $43 a$ & $\mathrm{H}$ & methoxy & 1-butylcyclopentyl & $<6.00(34 \%)$ & $\ll 6.00(-8 \%)$ \\
\hline $43 b$ & $\mathrm{H}$ & hydroxy & 1-butylcyclopentyl & $\ll 6.00(-13 \%)$ & $\ll 6.00(-21 \%)$ \\
\hline $44 a$ & o-methyl & methoxy & 1-butylcyclopentyl & $\ll 6.00(-32 \%)$ & $\ll 6.00(-14 \%)$ \\
\hline $44 \mathrm{~b}$ & $o$-methyl & hydroxy & 1-butylcyclopentyl & $\ll 6.00(4 \%)$ & $<6.00(43 \%)$ \\
\hline $47 a$ & o-methoxy & methoxy & 1-butylcyclopentyl & $\ll 6.00(-10 \%)$ & $\ll 6.00(-37 \%)$ \\
\hline $47 b$ & o-hydroxy & hydroxy & 1-butylcyclopentyl & $\ll 6.00(-43 \%)$ & $\ll 6.00(-2 \%)$ \\
\hline $52 \mathrm{a}$ & p-trifluoro-methyl & methoxy & 1-butylcyclopentyl & $\ll 6.00(3 \%)$ & $\ll 6.00(-4 \%)$ \\
\hline $52 b$ & p-trifluoro-methyl & hydroxy & 1-butylcyclopentyl & $\ll 6.00(-24 \%)$ & $\ll 6.00(-10 \%)$ \\
\hline
\end{tabular}

${ }^{c}$ Insufficient purity.

a Data from at least three individual experiments in duplicates.

b Data from at least two individual experiments in duplicates.

${ }^{\mathrm{d}} K_{\mathrm{i}} \pm \mathrm{SEM}(\underline{\mu \mathrm{M}})$ from at least three independent experiments in duplicates. 
Table 2

Efficacy results from [35S]GTP $\gamma \mathrm{S}$ binding assay and respective EC50 values for selected coumarin derivatives.

\begin{tabular}{|c|c|c|}
\hline Cpd. & $\mathrm{E}_{\max }$ effect on $\left[{ }^{35} \mathrm{~S}\right] \mathrm{GTP} \gamma \mathrm{S}$ binding to $\mathrm{hCB}_{1}{ }^{\mathrm{a}}\left(\mathrm{EC}_{50} \pm \mathrm{SEM}[\mu \mathrm{M}]\right)^{\mathrm{b}}$ & $\mathrm{E}_{\max }$ effect on $\left[{ }^{35} \mathrm{~S}\right] \mathrm{GTP} \gamma \mathrm{S}$ binding to $\mathrm{hCB}_{2}{ }^{\mathrm{a}}\left(\mathrm{EC}_{50} \pm \mathrm{SEM}[\mu \mathrm{M}]\right)^{\mathrm{b}}$ \\
\hline СР55.940 & $100 \pm 0(0.00151 \pm 0.00013)$ & $100 \pm 0(0.000540 \pm 0.000012)$ \\
\hline $24 a$ & $46 \pm 4(1.01 \pm 0.20)^{* * *}$ & $34 \pm 1(0.188 \pm 0.090)^{* * * *}$ \\
\hline $25 a$ & $40 \pm 3 * * *$ & $40 \pm 5^{* * * *}$ \\
\hline $28 b$ & n.d. & $82 \pm 2^{\mathrm{ns}}$ \\
\hline $30 \mathrm{~b}$ & n.d. & $68 \pm 4(0.042 \pm 0.007)^{*}$ \\
\hline $34 b$ & n.d. & $87 \pm 14^{\mathrm{ns}}$ \\
\hline $35 b$ & n.d. & $91 \pm 3^{\mathrm{ns}}$ \\
\hline $36 b$ & n.d. & $85 \pm 1(0.018 \pm 0.008)^{\mathrm{ns}}$ \\
\hline $37 b$ & n.d. & $66 \pm 6^{*}$ \\
\hline $38 b$ & n.d. & $65 \pm 3 * *$ \\
\hline $39 b$ & $23 \pm 6(1.12 \pm 0.49) * * * *$ & $62 \pm 3(0.00451 \pm 0.00279)^{* *}$ \\
\hline $40 \mathrm{~b}$ & n.d. & $65 \pm 1^{* *}$ \\
\hline
\end{tabular}

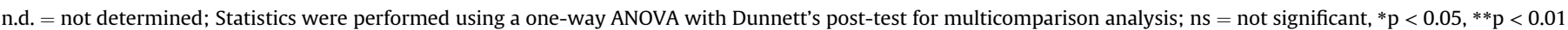
$* * * \mathrm{p}<0.001, * * * * \mathrm{p}<0.0001$.

${ }^{a} E_{\max }$ expressed as means \pm SEM relative to the max effect of full agonist CP55,940 at $1 \mu \mathrm{M}(=100 \%)$ of two individual experiments in duplicates.

b $\mathrm{EC}_{50}$ expressed as means \pm SEM relative to the max effect of full agonist CP55,940 of three individual experiments in duplicates.
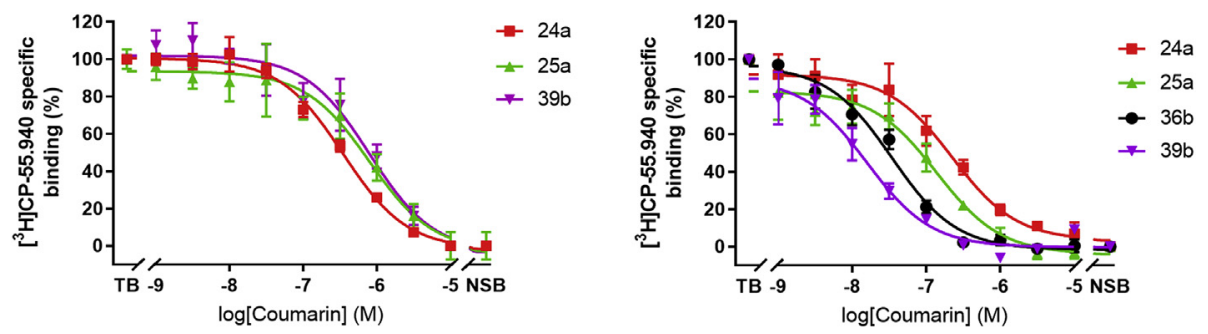

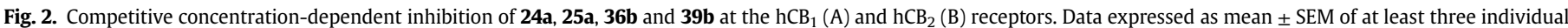
experiments in duplicates.

(a)

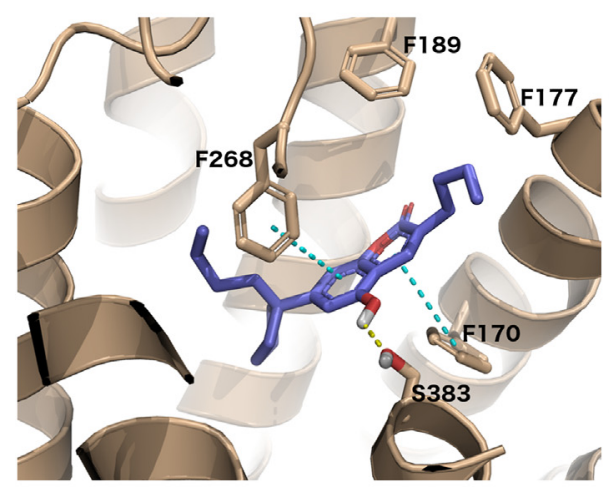

(b)

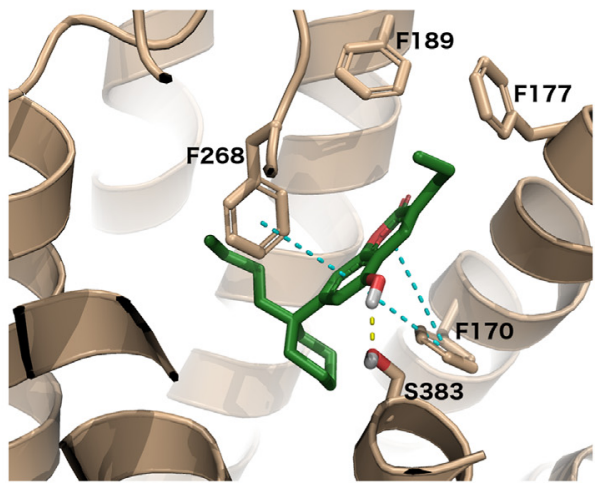

Fig. 3. Docking of $\mathbf{3 6 b}(\mathbf{A})$ and $\mathbf{3 9 b}(\mathbf{B})$ in a crystal structure of the $\mathrm{CB}_{1}$ receptor (PDB: $\left.5 \mathrm{XRA}\right)$. Important binding regions are highlighted (blue, black, and red circles).

mainly defined by $\mathrm{F} 200,{ }^{3.36} \mathrm{~L} 359,{ }^{6.51}$ and M363 ${ }^{6.55}$ forming an extended hydrophobic tunnel towards the residue of Y275 $5^{5.39}$ and the central polar region around AA S383 ${ }^{7.39}$ (red circle).

Although the crystal structure of the $\mathrm{CB}_{2} \mathrm{R}$ was unfit for docking as it represented the inactive state, it was observed that the $\mathrm{CB}_{2} \mathrm{R}$ binding pocket holds similar characteristics compared to the $\mathrm{CB}_{1} \mathrm{R}$. Two important regions were identified: a hydrophobic pocket at the top of the receptor-binding site defined by the AA residues of $\mathrm{F} 91^{2.61}, \mathrm{~F} 94^{2.64}, \mathrm{H}^{2} 5^{2.65}, \mathrm{~F} 106^{3.25}$, and $\mathrm{I} 110^{3.29}$, and the bottom region, showing an ambivalent hydrophobic and amphiphilic characteristic, restricted by the AA residues of $\mathrm{F} 117^{3.36}$, W194 ${ }^{5.43}$, W258 $8^{6.48}$, and V261 ${ }^{6.51}$. To achieve high binding affinities the data suggested that both pockets must be occupied, as shown for coumarins with large lipophilic groups pointing bidirectional away from the coumarin core (e.g. 36b and 39b, Fig. 3). The increased affinity for coumarins with a hydroxyl group at position 5 was structurally explained by strong polar interactions via hydrogen bonds towards centrally located AA residues $\mathrm{S} 285^{7.38}$ or T114 $4^{3.33}$.

\section{Conclusion}

In conclusion, we described the synthesis and SAR determinations, tested in radioligand binding studies, of a series of coumarin derivatives as potent and selective $\mathrm{CB}_{1}$ and/or $\mathrm{CB}_{2}$ receptor agonists. We observed several crucial requirements to obtain high receptor binding affinities. In general, a 7-alkyl chain was essential for any affinity at the receptors. Higher binding affinities were achieved by more profound filling of the hydrophobic tunnel towards $\mathrm{Y}_{275^{5.39}}$, whereby the length should not exceed six carbon atoms. For the tested $\mathrm{CB}_{2}$ ligands, stronger interactions inside the 
binding pocket resulted in a partial agonistic ligand and higher motility in full agonistic ligands. Structural flexibility at position 3 was crucial for any receptor affinity, shown by complete loss of activity for the 3-phenylcoumarin derivatives. Derivatives containing 3-alkyl chains only showed high affinities, if a bulky group at the 7-position was present. Benzyl groups are tolerated best if left unsubstituted or only substituted with small hydrophobic groups preferred in descending order from $o>m>p$. Heterocycles were tolerated if orientated in $o$ - or $m$-direction. Higher selectivity at $\mathrm{CB}_{2}$ was achieved by introducing a free hydroxyl group at the core structure.

Nevertheless, additional studies are aimed to further determine the pharmacological properties and potential off-target activities to the CBS-related GPCRs GPR55 and GPR118.

\section{Experimental section}

Syntheses. All commercially reagents and solvents were obtained from various producers and used without further purification. ${ }^{1} \mathrm{H},{ }^{13} \mathrm{C}$ and ${ }^{19} \mathrm{~F}$ NMR spectra were recorded on a Bruker Avance 300 (300 MHz), Bruker Avance 400 (400 MHz) and Bruker Avance $500 \mathrm{DRX}(500 \mathrm{MHz})$. Deuterated DMSO- $d_{6}, \mathrm{CDCl}_{3}$, or acetone- $d_{6}$ were used as solvents and internal references. Chemical shifts $(\delta)$ are reported in ppm relative to the reference and coupling constants $(J)$ are reported in hertz $(\mathrm{Hz})$. Thin-layer chromatography (TLC) was performed on precoated silica gel $60 \mathrm{~F}_{254}$ plates purchased from Merck and spots were visualized by UV light or staining solutions. Normal phase flash column chromatography was carried out using Merck silica gel 60 (mesh 230-400). Reversed-phase high-performance chromatography (HPLC) was carried out on a Jasco LC-NetII/ADC system using a preparative VDSpher C18 column $(10 \mu \mathrm{m}, 250 \times 20 \mathrm{~mm})$ with varying ratios of acetonitrile and $0.1 \%$ trifluoroacetic acid in water as solvent system. IR spectra were recorded on a Bruker Alpha P using Attenuated Total Reflection (ATR). Mass and high-resolution mass spectra were obtained using a Finnigan Mat 95 (EI, MS, and HRMS) and Thermo Scientific QExactive Plus (ESI, HRMS only). Purities were determined by NMR and only compounds with a purity $\geq 95 \%$ were tested.

General Procedure A, for the synthesis of 3-benzyl- or 3pyridinyl coumarins.

Under an atmosphere of argon, a microwave vial was charged with the respective salicylic aldehyde (1.00 equiv.), cinnamaldehyde (2.50 equiv.), $\mathrm{K}_{2} \mathrm{CO}_{3} \quad(1.20$ equiv.) and 1,3dimethylimidazolium dimethyl phosphate (1.20-1.50 equiv.) and suspended in abs. toluene $(3.30 \mathrm{~mL} / \mathrm{mmol}$ salicylic aldehyde). The reaction mixture was stirred at $230 \mathrm{~W}$ and heated to $110^{\circ} \mathrm{C}$ at 7 bars for 50 min in the CEM Discover SP microwave reactor. The reaction mixture was diluted with $\mathrm{H}_{2} \mathrm{O}$ and extracted with ethyl acetate, the combined organic phases were dried over $\mathrm{Na}_{2} \mathrm{SO}_{4}$, filtrated, and concentrated in vacuo. The crude product was purified by flash column chromatography.

5-Methoxy-7-pentyl-3-(pyridin-2-ylmethyl)-2H-chromen-2one (24a) Prepared from 2-hydroxy-6-methoxy-4pentylbenzaldehyde $(\mathbf{6 d}, 150 \mathrm{mg}, 0.68 \mathrm{mmol})$ according to general procedure A as off-white solid ( $41.8 \mathrm{mg}, 18 \%)$. $R_{\mathrm{f}}$ (cHex/EtOAc $1: 1)=0.19 .{ }^{1} \mathrm{H}$ NMR $\left(400 \mathrm{MHz}, \mathrm{CDCl}_{3}\right): \delta 8.53(\mathrm{ddd}, J=4.9,1.9$, $0.9 \mathrm{~Hz}, 1 \mathrm{H}), 7.97(\mathrm{~s}, 1 \mathrm{H}), 7.61(\mathrm{td}, J=7.7,1.8 \mathrm{~Hz}, 1 \mathrm{H}), 7.37(\mathrm{dt}, J=7.8$, $1.1 \mathrm{~Hz}, 1 \mathrm{H}), 7.13$ (ddd, $J=7.6,4.9,1.2 \mathrm{~Hz}, 1 \mathrm{H}), 6.71(\mathrm{~d}, J=1.2 \mathrm{~Hz}, 1 \mathrm{H})$, $6.49(\mathrm{~d}, J=1.3 \mathrm{~Hz}, 1 \mathrm{H}), 4.04(\mathrm{~d}, J=1.0 \mathrm{~Hz}, 2 \mathrm{H}), 3.87(\mathrm{~s}, 3 \mathrm{H})$, 2.66-2.58 (m, 2H), 1.69-1.55 (m, 2H), 1.42-1.22 (m, 4H), $0.88(\mathrm{t}$, $J=6.8 \mathrm{~Hz}, 3 \mathrm{H})$ ppm. ${ }^{13} \mathrm{C} \mathrm{NMR}\left(101 \mathrm{MHz}, \mathrm{CDCl}_{3}\right): \delta 162.1,158.6,155.7$, $154.5,149.6,147.9,136.8,136.0,124.1,123.9,121.8,108.5,108.2$, 105.7, 55.9, 39.7, 36.7, 31.5, 30.8, 22.6, 14.1 ppm. IR (ATR, KBr) ṽ: 2927, 2855, 1701, 1613, 1568, 1495, 1426, 1297, 1255, 1182, 1139, 1111,
1055, 995, 832, 766, 745, 688, 628, 601, 573, 490, $403 \mathrm{~cm}^{-1}$. MS (70 eV, EI) m/z (\%): 337/338 (100/25) [M] $]^{+}$. HRMS (EI, $\left.\mathrm{C}_{21} \mathrm{H}_{23} \mathrm{O}_{3} \mathrm{~N}\right)$ : calc. 337.1672, found 337.1672.

General Procedure B, for the synthesis of 3-alkylcoumarins.

Under an atmosphere of argon, a microwave vial was charged with the respective salicylic aldehyde ( 1.00 equiv.) and $\mathrm{K}_{2} \mathrm{CO}_{3}(0.05$ equiv.) and suspended in carboxylic acid anhydride (3.50 equiv.). The reaction mixture was stirred at $230 \mathrm{~W}$ and heated to $180^{\circ} \mathrm{C}$ at 7 bars for $65 \mathrm{~min}$ in the CEM Discover SP microwave reactor. The reaction mixture was diluted with $\mathrm{H}_{2} \mathrm{O}$, the $\mathrm{pH}$ adjusted to $\sim 7$, and extracted with ethyl acetate. The combined organic phases were dried over $\mathrm{Na}_{2} \mathrm{SO}_{4}$, filtrated, and concentrated in vacuo. The crude product was purified by flash column chromatography.

7-(1-Butylcyclopentyl)-5-methoxy-3-propyl-2H-chromen-2one (35a) Prepared from 4-(1-butylcyclopentyl)-2-hydroxy-6methoxybenzaldehyde (6e, $200 \mathrm{mg}, 0.72 \mathrm{mmol}$ ) according to general procedure B as off-white solid $(227 \mathrm{mg}, 92 \%) . R_{\mathrm{f}}$ (cHex/EtOAc 50:1): 0.29. ${ }^{1} \mathrm{H}$ NMR (400 MHz, $\left.\mathrm{CDCl}_{3}\right): \delta 7.80(\mathrm{~s}, 1 \mathrm{H}), 6.82(\mathrm{~d}$, $J=1.3 \mathrm{~Hz}, 1 \mathrm{H}), 6.61(\mathrm{~d}, J=1.4 \mathrm{~Hz}, 1 \mathrm{H}), 3.92(\mathrm{~s}, 3 \mathrm{H}), 2.52(\mathrm{td}, J=7.6$, $1.1 \mathrm{~Hz}, 2 \mathrm{H}), 1.96-1.76(\mathrm{~m}, 4 \mathrm{H}), 1.76-1.53(\mathrm{~m}, 8 \mathrm{H}), 1.15(\mathrm{p}, J=7.3 \mathrm{~Hz}$, $2 \mathrm{H}), 0.98(\mathrm{t}, J=7.3 \mathrm{~Hz}, 3 \mathrm{H}), 0.97-0.89(\mathrm{~m}, 2 \mathrm{H}), 0.78(\mathrm{t}, J=7.3 \mathrm{~Hz}$, $3 \mathrm{H}) \mathrm{ppm} .{ }^{13} \mathrm{C}$ NMR $\left(101 \mathrm{MHz}, \mathrm{CDCl}_{3}\right): \delta 162.4,155.1,154.0,153.8$, 133.7, 126.8, 107.9, 107.6, 104.0, 55.9, 52.0, 41.7, 37.8, 33.1, 27.6, 23.4, 23.3, 21.6, 14.1, 13.9 ppm. IR (ATR, KBr) ṽ: 2954, 2925, 2869, 1712, 1612, 1571, 1494, 1454, 1414, 1351, 1288, 1246, 1167, 1104, 1051, 1026, 923, 902, 841, 772, 714, $557 \mathrm{~cm}^{-1}$. MS (70 eV, EI) m/z (\%): 342 (53) $[\mathrm{M}]^{+}, 285$ (100). HRMS (EI, $\mathrm{C}_{22} \mathrm{H}_{30} \mathrm{O}_{3}$ ): calc. 342.2192, found 342.2189 .

General Procedure $\mathbf{C}$, for the cleavage of methoxy groups.

Under an atmosphere of argon, to a solution of the respective coumarin (1.00 equiv.) in dichloromethane $(10 \mathrm{~mL} / \mathrm{mmol})$, boron tribromide (1 $\mathrm{M}$ in dichloromethane, 5.00 equiv./methoxy group) were added dropwise at $-78{ }^{\circ} \mathrm{C}$. At this temperature, the reaction mixture was stirred for $30 \mathrm{~min}$ and then stirred at room temperature for another $15-20 \mathrm{~h}$. The reaction was quenched by the addition of aqueous saturated $\mathrm{NaHCO}_{3}$ solution, extracted with dichloromethane, and washed with distilled water and brine. The combined organic phases were dried over $\mathrm{Na}_{2} \mathrm{SO}_{4}$, filtrated, and concentrated in vacuo. The crude product was purified by filtration over a small silica pad or flash column chromatography.

7-(1-Butylcyclohexyl)-5-hydroxy-3-(pyridin-2-ylmethyl)-2Hchromen-2-one (30b) Prepared from 5-methoxycoumarin 30a ( $19.0 \mathrm{mg}, 47.0 \mu \mathrm{mol}$ ) according to general procedure $\mathrm{C}$ as yellow oil $(8.9 \mathrm{mg}, 49 \%) . R_{\mathrm{f}}(\mathrm{cHex} /$ EtOAc $1: 2)=0.35 .{ }^{1} \mathrm{H} \mathrm{NMR}(400 \mathrm{MHz}$, $\left.\mathrm{CDCl}_{3}\right): \delta 11.82(\mathrm{bs}, 1 \mathrm{H}), 8.62(\mathrm{~s}, 1 \mathrm{H}), 8.47-8.41(\mathrm{~m}, 1 \mathrm{H}), 7.83-7.73$ $(\mathrm{m}, 2 \mathrm{H}), 7.29$ (ddd, $J=7.0,5.1,1.7 \mathrm{~Hz}, 1 \mathrm{H}), 6.63-6.57(\mathrm{~m}, 2 \mathrm{H}), 4.06(\mathrm{~s}$, $2 \mathrm{H}), 1.82(\mathrm{~d}, J=11.9 \mathrm{~Hz}, 2 \mathrm{H}), 1.46-1.29(\mathrm{~m}, 6 \mathrm{H}), 1.27-1.20(\mathrm{~m}, 4 \mathrm{H})$, $1.10-0.99(\mathrm{~m}, 2 \mathrm{H}), 0.86-0.76(\mathrm{~m}, 2 \mathrm{H}), 0.69(\mathrm{t}, J=7.3 \mathrm{~Hz}, 3 \mathrm{H}) \mathrm{ppm}$. ${ }^{13} \mathrm{C} \mathrm{NMR}\left(101 \mathrm{MHz}, \mathrm{CDCl}_{3}\right): \delta 162.5,158.0,154.9,154.7,153.5,146.6$, 139.4, 139.1, 126.6, 123.0, 121.0, 108.9, 107.4, 106.1, 42.0, 38.9, 36.4, 29.9, 26.6, 25.8, 23.4, 22.5, 14.2 ppm. IR (ATR, KBr) ṽ: 2925, 2855, $1710,1617,1570,1420,1341,1290,1255,1184,1079,1058,1009,908$, $840,768,729,673,636,604,528,409 \mathrm{~cm}^{-1}$. MS (70 eV, EI) m/z (\%): $391(61)[\mathrm{M}]^{+}, 334(39)\left[\mathrm{M}-\mathrm{C}_{4} \mathrm{H}_{9}\right]^{+}, 57(100)\left[\mathrm{C}_{4} \mathrm{H}_{9}\right]^{+}$. HRMS (EI, $\left.\mathrm{C}_{25} \mathrm{H}_{29} \mathrm{O}_{3} \mathrm{~N}\right)$ : calc. 391.2147, found 391.2146.

General procedure D, for the synthesis of 3-arylcoumarins.

A crimp vial was charged with the respective 3-bromo coumarin (1.00 equiv.), the respective boronic acid (2.00 equiv.), cesium carbonate ( 2.00 equiv.), and tetrakistriphenylphosphine palladium ( 0 ) and abs. 1,4-dioxane ( $1.00 \mathrm{~mL} / 0.1 \mathrm{mmol}$ of bromide) was added. The mixture was degassed by three freeze-pump-thaw cycles, put under an atmosphere of argon, and stirred at $90{ }^{\circ} \mathrm{C}$ for $16 \mathrm{~h}$. After cooling to room temperature, the reaction was quenched by the addition of water, the aqueous phase was extracted with ethyl acetate and the combined organic phases were dried over $\mathrm{Na}_{2} \mathrm{SO}_{4}$, 
filtrated, and concentrated in vacuo. The crude product was purified by flash column chromatography.

7-(1-Butylcyclopentyl)-5-methoxy-3-phenyl-2H-chromen-2one (43a) Prepared from 3-bromo-7-(1-butylcyclopentyl)-5methoxy-2H-chromen-2-one $(\mathbf{4 2}, 100 \mathrm{mg}, 0.26 \mathrm{mmol})$ according to general procedure $\mathrm{D}$ as colorless oil $(82 \mathrm{mg}, 82 \%) . R_{\mathrm{f}}$ (cHex/EtOAc $10: 1)=0.52 .{ }^{1} \mathrm{H} \mathrm{NMR}\left(400 \mathrm{MHz}, \mathrm{CDCl}_{3}\right): \delta 8.17(\mathrm{~s}, 1 \mathrm{H}), 7.76-7.68(\mathrm{~m}$, $2 \mathrm{H}), 7.48-7.40(\mathrm{~m}, 2 \mathrm{H}), 7.40-7.33(\mathrm{~m}, 1 \mathrm{H}), 6.89(\mathrm{~d}, J=1.4 \mathrm{~Hz}, 1 \mathrm{H})$, $6.65(\mathrm{~d}, J=1.5 \mathrm{~Hz}, 1 \mathrm{H}), 3.95(\mathrm{~s}, 3 \mathrm{H}), 1.98-1.57(\mathrm{~m}, 10 \mathrm{H}), 1.23-1.13$ $(\mathrm{m}, 2 \mathrm{H}), 1.03-0.90(\mathrm{~m}, 2 \mathrm{H}), 0.80(\mathrm{t}, J=7.3 \mathrm{~Hz}, 3 \mathrm{H}) \mathrm{ppm} .{ }^{13} \mathrm{C} \mathrm{NMR}$ $\left(101 \mathrm{MHz}, \mathrm{CDCl}_{3}\right): \delta 161.5,156.2,155.5,154.7,135.9,135.6,129.0$, 128.8, 125.7, 108.6, 107.9, 104.5, 56.3, 52.5, 42.0, 38.2, 28.0, 23.7, 23.7, 14.5 ppm. IR (KBr) ṽ: 2927, 2868, 1760, 1721, 1611, 1563, 1487, 1459, 1415, 1350, 1280, 1232, 1212, 1101, 952, 841, 785, 755, 734, 693, 641, 591, 557, $515 \mathrm{~cm}^{-1}$. MS (70 eV, EI) m/z (\%): 376 (87) [M] ${ }^{+}, 319$ (95) $\left[\mathrm{M}-\mathrm{C}_{4} \mathrm{H}_{9}\right]^{+}, 84$ (100). HRMS (EI, $\mathrm{C}_{25} \mathrm{H}_{28} \mathrm{O}_{3}$ ): calc. 376.2033, found 376.2032.

Biology. The PathHunter ${ }^{\circledR}$ CHOK1hCB1_bgal and CHOK1hCB2_bgal (catalog number 93-0959C2 and 93-0706C2) $\beta$ Arestin cell lines cells were purchased from Eurofins DiscoverX (Fremont, CA). Cell culture plates were purchased from Sarstedt (Nürnbrecht, Germany). Bicinchoninic acid (BCA) and the BSA protein assay reagents were purchased from Pierce Chemical Company (Rochford, IL). [ $\left.{ }^{3} \mathrm{H}\right] \mathrm{CP} 55,940$ (specific activity $149 \mathrm{Ci} /$ $\mathrm{mmol}$ ), $\left[{ }^{35} \mathrm{~S}\right] \mathrm{GTP} \gamma \mathrm{S}$ (specific activity $1250 \mathrm{Ci} / \mathrm{mmol}$ ), and GF-B/GF-C plates were purchased from PerkinElmer (Waltham, MA). CB receptor reference standards Rimonabant and AM630 were purchased from Cayman Chemical Company, CP55,940 were purchased from Sigma Aldrich (St. Louis, MO). All solutions and buffers were prepared using Millipore water (deionization by MilliQ A10 Bio-

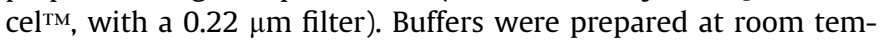
perature and, if not stated otherwise, stored at $4{ }^{\circ} \mathrm{C}$. All solvents and reagents were used as an analytical grade. Different concentrations of compounds were added using an HP D300 Digital Dispenser (Tecan, Männedorf. Switzerland) and the DMSO stock solutions. In all assays, the final concentration of DMSO/assay point was limited to $\leq 1 \%$. Single point assays were performed at $1 \mu \mathrm{M}$ of the competing ligand and at least two individual experiments in duplicates. Full-curve assays were performed with ten concentrations of the competing ligand to determine the pKi values and at least three individual experiments in duplicates. Errors are expressed as the standard error of the mean (SEM).

Cell culture. CHOK1hCB1_bgal and CHOK1hCB2_bgal were cultured in modified Ham's F12 Nutrient Mixture supplemented with GlutaMAX ${ }^{\mathrm{TM}}$ as glutamine source. Additional supplements were $10 \%$ fetal calf serum (FCS), $50 \mu \mathrm{g} / \mathrm{mL}$ penicillin, $50 \mu \mathrm{g} / \mathrm{mL}$ streptomycin, $300 \mathrm{mg} / \mathrm{mL}$ hygromycin and $800 \mu \mathrm{g} / \mathrm{mL}$ geneticin in a humidified atmosphere at $37{ }^{\circ} \mathrm{C}$ and $5 \% \mathrm{CO}_{2}$. Cells were subcultured twice a week at a confluence of $\sim 90 \%$ and a ratio of $1: 10$ on $10-\mathrm{cm}$ diameter plates by trypsinization. Two days before membrane preparation the cells were sub-cultured $1: 20$ on $15-\mathrm{cm}$ diameter plates. Membrane preparations were performed as previously described [26]. The final membrane pellet was resuspended in $10 \mathrm{~mL}$ ice-cold $50 \mathrm{mM}$ Tris- $\mathrm{HCl}$ buffer ( $\mathrm{pH} 7.4$ ) and $5 \mathrm{mM} \mathrm{MgCl}_{2}$ and aliquots of $200 \mu \mathrm{L} \quad$ (CHOK1hCB1_bgal) or $50 \mu \mathrm{L}$ (CHOK1hCB2_bgal), respectively, were stored at $-80{ }^{\circ} \mathrm{C}$ until further use. The membrane concentrations were measured using the BCA method [27].

Equilibrium radioligand displacement assay. $\left[{ }^{3} \mathrm{H}\right] \mathrm{CP} 55,940$ displacement assay on 96-well plate was used for the determination of affinity $\left(\mathrm{IC}_{50}\right.$ and $\mathrm{K}_{\mathrm{i}}$ ) values of coumarin-derivatives for the recombinant human cannabinoid receptors $\mathrm{CB}_{1}$ and $\mathrm{CB}_{2}$. Membrane aliquots containing $5 \mu \mathrm{g}$ (CHOK1hCB1_bgal) or $1.5 \mu \mathrm{g}$ (CHOK1hCB2_bgal) protein were incubated under shaking $(\sim 400 \mathrm{rpm})$ in a total volume of $100 \mu \mathrm{L}$ assay buffer $(50 \mathrm{mM}$ Tris- $\mathrm{HCl}$ buffer ( $\mathrm{pH} 7.4$ ), $5 \mathrm{mM} \mathrm{MgCl} 2$ and $0.1 \% \mathrm{BSA}$ ) and in the presence of $\sim 1.5 \mathrm{nM}\left[{ }^{3} \mathrm{H}\right] \mathrm{CP} 55,940$ at $25{ }^{\circ} \mathrm{C}$ for $2 \mathrm{~h}$. Nonspecific binding (NSB) was determined in the presence of $10 \mu \mathrm{M}$ Rimonabant (CHOK1hCB1_bgal) or AM630 (CHOK1hCB2_bgal). Incubation was terminated by rapid filtration on 96-well GF/C filter plates (PERKIN Elmer, Groningen, the Netherlands), pre-coated with PEI (Polyethyleneimine), using a Perkin Elmer 96-well harvester (Perkin Elmer, Groningen, the Netherlands). To remove free radioligand the filters were washed ten times with ice-cold assay buffer $(50 \mathrm{mM}$ Tris- $\mathrm{HCl}$ buffer ( $\mathrm{pH} 7.4$ ), $5 \mathrm{mM} \mathrm{MgCl}_{2}$, and $0.1 \% \mathrm{BSA}$ ) twice, followed by drying the filters at $55{ }^{\circ} \mathrm{C}$ for $30 \mathrm{~min}$. After $3 \mathrm{~h}$ pre-incubation in scintillation fluid, the filter-bound radioactivity was determined by scintillation spectrometry, using a MicROBETA2 $® 2450$ microplate counter (PERKIn Elmer, Boston, MA).

$\left[{ }^{35} \mathbf{S}\right] \mathbf{G T P} \gamma \mathbf{S}$ binding assay. $\mathrm{G}$ protein activation measurements as a consequence of receptor activity were performed by preincubation of $5 \mu \mathrm{g}$ CHOK1hCB1_bgal or CHOK1hCB2_bgal membranes in a total volume of $100 \mu \mathrm{L}$ assay buffer $(50 \mathrm{mM}$ Tris- $\mathrm{HCl}$ buffer (pH 7.4), $5 \mathrm{mM} \mathrm{MgCl}$, $150 \mathrm{mM} \mathrm{NaCl}, 1 \mathrm{mM}$ EDTA, 0.05\% BSA and $1 \mathrm{mM}$ DTT, freshly prepared every day) supplemented with $1 \mu \mathrm{M}$ GDP and $5 \mu \mathrm{g}$ saponin (final concentration) and different concentrations of the ligands of interest for $30 \mathrm{~min}$ at room temperature. Subsequently, after pre-incubation, $\left[{ }^{35} \mathrm{~S}\right] \mathrm{GTP} \gamma \mathrm{S}(0.3 \mathrm{nM}$, final concentration) was added and incubation continued at $25{ }^{\circ} \mathrm{C}$ and $400 \mathrm{rpm}$ for $90 \mathrm{~min}$. The basal level of $\left[{ }^{35} \mathrm{~S}\right] \mathrm{GTP} \gamma \mathrm{S}$ binding was measured in untreated membrane samples, and the maximal level of $\left.{ }^{35} \mathrm{~S}\right] \mathrm{GTP} \gamma \mathrm{S}$ binding was measured with $10 \mu \mathrm{M}$ CP55,940 as reference. Incubation was terminated by rapid filtration on 96 -well $\mathrm{GF} / \mathrm{B}$ plates (as described above), except instead using GF/B filter plates and washing buffer containing $50 \mathrm{mM}$ Tris- $\mathrm{HCl}$ buffer $(\mathrm{pH}$ 7.4), $5 \mathrm{mM} \mathrm{MgCl}$.

Data analysis. All experimental data from the assays were analyzed with GraphPad Prism (GraphPad Software Inc., San Diego, CA, version 7 and 8). For $\left[{ }^{3} \mathrm{H}\right] \mathrm{CP} 55,940$ displacement assays, nonlinear regression analysis for "one site - Fit Ki" was used to obtain $\log K_{\mathrm{i}}$ values, which were calculated by direct application of the Cheng-Prusoff equation [28]: $\mathrm{K}_{\mathrm{i}}=\mathrm{IC}_{50} /\left(1+\left([\mathrm{L}] / \mathrm{K}_{\mathrm{D}}\right)\right)$, where [L] described the exact concentration of $\left[{ }^{3} \mathrm{H}\right] \mathrm{CP} 55,940$ (determined each experiment, $\sim 1.5 \mathrm{nM}$ ). The kinetic $K_{\mathrm{D}}$ was calculated by using the equation $K_{\mathrm{D}}=k_{\text {off }} / k_{\text {on }}$ and was determined for $\mathrm{CB}_{1}(0.41 \pm 0.08 \mathrm{nM})$ using an association $\left(K_{\text {on }}=4.49 \pm 0.21 \times 10^{7} \mathrm{M}^{-1} \mathrm{~s}^{-1}\right)$ and dissociation assay $\left(K_{\text {off }}=1.85 \pm 0.41 \times 10^{-2} \mathrm{~s}^{-1}\right)$, respectively (three individual experiments in duplicates, data not shown) and for $\mathrm{CB}_{2}$ $(1.24 \pm 0.10 \mathrm{nM})$ as previously reported [29]. The observed rate constant $\left(k_{\text {obs }}\right)$ values from the kinetic experiments were converted by fitting them to a "one-phase exponential association analysis" for $k_{\mathrm{on}}$, using the equation $k_{\mathrm{on}}=\left(k_{\mathrm{obs}}-k_{\mathrm{off}}\right) /[\mathrm{L}]$, where [L] is the exact concentration of $\left[{ }^{3} \mathrm{H}\right] \mathrm{CP} 55,940$ for each experiment and a "one-phase exponential decay" for $k_{\text {off. }}$ Results of the GTP $\gamma \mathrm{S}$ assay were analyzed with a nonlinear regression analysis "log (agonist) vs. response variable slope" to calculate the potency $\left(\mathrm{EC}_{50}\right)$ and the efficacy $\left(\mathrm{E}_{\max }\right.$.) of the ligands. The efficacy of agonistic ligands was normalized to the effect of $10 \mu \mathrm{M}\left[{ }^{3} \mathrm{H}\right] \mathrm{CP} 55,940$ as $100 \%$ and the basal activity as $0 \%$. For statistical analysis of a correlation between two independent variables, a one-way ANOVA correlation analysis was applied, with a Pvalue of 0.05 as statistically significant.

Computational studies. Preparation steps and docking were performed using Schrödinger (Schrödinger, LC, New York, NY, 2018; version 2018-2) [30]. Crystal structures of $\mathrm{CB}_{1}$ (PDB: 5XRA) [24] and $\mathrm{CB}_{2}$ (PDB: 5ZTY) [25] were prepared using protein preparation by which disulfide bridges were created, and explicit hydrogens and missing side chains were added. Compounds were prepared for docking using Ligprep, generating states at $\mathrm{pH}$ 7. A maximum of ten docked poses was generated per compound. Docking was performed without constraints. The agonistic ligands were docked in 
an active conformation of the $C_{1}$ receptor. However, for $C_{2}$ no active state crystal structure was available, therefore docking was performed on an inactive $\mathrm{CB}_{2}$ receptor conformation.

Crystal Structure Determination of $\mathbf{4 4 b}$. The single-crystal Xray diffraction studies were carried out on a Bruker D8 Venture diffractometer with Photon 100 at 123 (2) K using $\mathrm{Cu}-\mathrm{K} \alpha$ radiation ( $\lambda=1.54178 \AA$ ) (for details see cif-files and supporting information).

CCDC 2022817 (44b) contains the supplementary crystallographic data for this paper. These data can be obtained free of charge from The Cambridge Crystallographic Data Centre via www. ccdc.cam.ac.uk/data_request/cif.

\section{Author contributions}

Chemical syntheses were done by Florian Mohr, Thomas Hurrle, Lukas Langer and Maximilian Knab and supervised by Stefan Bräse. The bioassays were conducted by Florian Mohr and supervised by Laura Heitman. Computational studies were performed by Lindsey Burggraaff and Martijn Bemelmans, supervised by Gerard J. P. van Westen. The crystallographic data were measured and analyzed by Martin Nieger. The manuscript was written by Florian Mohr, supported by the co-authors. All authors have approved the final version of the manuscript.

\section{Funding sources}

FDM was funded by an LGFG Ph.D. scholarship of the KHYS.

\section{Declaration of competing interest}

The authors declare that they have no known competing financial interests or personal relationships that could have appeared to influence the work reported in this paper.

\section{Acknowledgment}

FDM thanks the KHYS for funding this research by an LGFG Ph.D. scholarship and Cas van der Horst for technical assistance. We acknowledge the DFG-core facility Molecule Archive (DFG project number: 284178167) for the management and provision of the compounds for screening.

\section{Appendix A. Supplementary data}

Supplementary data to this article can be found online at https://doi.org/10.1016/j.ejmech.2021.113354.

\section{Abbreviations}

\section{CB cannabinoid}

CHO cells Chinese hamster ovary cells

ECS endocannabinoid system

FCS fetal calf serum

GPCR G-protein coupled receptor

NBS non-specific binding

n.d. not determined

SEM standard error of the mean

SAR structure-activity relationship

THC tetrahydrocannabinol

TM transmembrane

\section{References}

[1] L.A. Matsuda, S.J. Lolait, M.J. Brownstein, A.C. Young, T.I. Bonner, Structure of a cannabinoid receptor and functional expression of the cloned cDNA, Nature 346 (6284) (1990) 561-564.

[2] S. Munro, K.L. Thomas, M. Abu-Shaar, Molecular characterization of a peripheral receptor for cannabinoids, Nature 365 (6441) (1993) 61-65.

[3] R.G. Pertwee, Pharmacological actions of cannabinoids, in: Cannabinoids, Springer, 2005, pp. 1-51.

[4] R. Mechoulam, L.A. Parker, The endocannabinoid system and the brain, Annu. Rev. Psychol. 64 (2013) 21-47.

[5] S.C. Azad, K. Monory, G. Marsicano, B.F. Cravatt, B. Lutz, W. Zieglgänsberger, G. Rammes, Circuitry for associative plasticity in the amygdala involves endocannabinoid signaling, J. Neurosci. 24 (44) (2004) 9953-9961.

[6] A. Calignano, G. La Rana, A. Giuffrida, D. Piomelli, Control of pain initiation by endogenous cannabinoids, Nature 394 (6690) (1998) 277.

[7] V. Di Marzo, I. Matias, Endocannabinoid control of food intake and energy balance, Nat. Neurosci. 8 (5) (2005) 585.

[8] A. Ligresti, L. De Petrocellis, V. Di Marzo, From phytocannabinoids to cannabinoid receptors and endocannabinoids: pleiotropic physiological and pathological roles through complex pharmacology, Physiol. Rev. 96 (4) (2016) 1593-1659.

[9] J.M. Gray, H.A. Vecchiarelli, M. Morena, T.T.Y. Lee, D.J. Hermanson, A.B. Kim, R.J. McLaughlin, K.I. Hassan, C. Kühne, C.T. Wotjak, J.M. Deussing, S. Patel, M.N. Hill, Corticotropin-releasing hormone drives anandamide hydrolysis in the amygdala to promote anxiety, J. Neurosci. 35 (9) (2015) 3879-3892.

[10] S.W. Saliba, H. Jauch, B. Gargouri, A. Keil, T. Hurrle, N. Volz, F. Mohr, M. van der Stelt, S. Bräse, B.L. Fiebich, Anti-neuroinflammatory effects of GPR55 antagonists in LPS-activated primary microglial cells, J. Neuroinflammation 15 (1) (2018) 322.

[11] Y. Nakajima, Y. Furuichi, K.K. Biswas, T. Hashiguchi, K.-i. Kawahara, K. Yamaji, T. Uchimura, Y. Izumi, I. Maruyama, Endocannabinoid, anandamide in gingival tissue regulates the periodontal inflammation through $\mathrm{NF}-\kappa \mathrm{B}$ pathway inhibition, FEBS Lett. 580 (2) (2006) 613-619.

[12] B.F. Cravatt, D.K. Giang, S.P. Mayfield, D.L. Boger, R.A. Lerner, N.B. Gilula, Molecular characterization of an enzyme that degrades neuromodulatory fatty-acid amides, Nature 384 (6604) (1996) 83.

[13] J.E. Nielsen, A.D. Rolland, E. Rajpert-De Meyts, C. Janfelt, A. Jørgensen, S.B. Winge, D.M. Kristensen, A. Juul, F. Chalmel, B. Jégou, Characterisation and localisation of the endocannabinoid system components in the adult human testis, Sci. Rep. 9 (1) (2019) 1-14.

[14] G. Astarita, D. Piomelli, Lipidomic analysis of endocannabinoid metabolism in biological samples, J. Chromatogr. B 877 (26) (2009) 2755-2767.

[15] M. Aghazadeh Tabrizi, P.G. Baraldi, P.A. Borea, K. Varani, Medicinal chemistry, pharmacology, and potential therapeutic benefits of cannabinoid CB2 receptor agonists, Chem. Rev. 116 (2) (2016) 519-560.

[16] B.J. Cridge, R.J. Rosengren, Critical appraisal of the potential use of cannabinoids in cancer management, Canc. Manag. Res. 5 (2013) 301.

[17] A. Behrenswerth, N. Volz, J. Toräng, S. Hinz, S. Bräse, C.E. Müller, Synthesis and pharmacological evaluation of coumarin derivatives as cannabinoid receptor antagonists and inverse agonists, Biorg. Med. Chem. 17 (7) (2009) 2842-2851.

[18] V. Rempel, N. Volz, S. Hinz, T. Karcz, I. Meliciani, M. Nieger, W. Wenzel, S. Bräse, C.E. Müller, 7-Alkyl-3-benzylcoumarins: a versatile scaffold for the development of potent and selective cannabinoid receptor agonists and antagonists, J. Med. Chem. 55 (18) (2012) 7967-7977.

[19] V. Rempel, N. Volz, F. Gläser, M. Nieger, S. Bräse, C.E. Müller, Antagonists for the orphan G-protein-coupled receptor GPR55 based on a coumarin scaffold, J. Med. Chem. 56 (11) (2013) 4798-4810.

[20] A. Howlett, F. Barth, T. Bonner, G. Cabral, P. Casellas, W. Devane, C. Felder, M. Herkenham, K. Mackie, B. Martin, International union of pharmacology. XXVII. Classification of cannabinoid receptors, Pharmacol. Rev. 54 (2) (2002) $161-202$.

[21] T. Hurrle, Synthesis of Cannabinoid Ligands: Novel Compound Classes, Routes and Perspectives, vol. 73, Logos Verlag Berlin GmbH, 2018.

[22] F. Mohr, Synthetic Cannabinoids in Drug Discovery. Design, Synthesis and Evaluation of Modified Coumarins as CB Receptor Ligands, vol. 88, Logos Verlag Berlin GmbH, 2020.

[23] L. Florekova, R. Flašík, H. Stankovičová, A. Gáplovský, Efficient synthesis of 3methyl-2 H-chromen-2-one: classic versus microwave conditions, Synth. Commun. 41 (10) (2011) 1514-1519.

[24] T. Hua, K. Vemuri, S.P. Nikas, R.B. Laprairie, Y. Wu, L. Qu, M. Pu, A. Korde, S. Jiang, J.-H. Ho, G.W. Han, K. Ding, X. Li, H. Liu, M.A. Hanson, S. Zhao, L.M. Bohn, A. Makriyannis, R.C. Stevens, Z.-J. Liu, Crystal structures of agonistbound human cannabinoid receptor CB1, Nature 547 (2017) 468.

[25] X. Li, T. Hua, K. Vemuri, J.-H. Ho, Y. Wu, L. Wu, P. Popov, O. Benchama, N. Zvonok, K.a. Locke, L. Qu, G.W. Han, M.R. Iyer, R. Cinar, N.J. Coffey, J. Wang, M. Wu, V. Katritch, S. Zhao, G. Kunos, L.M. Bohn, A. Makriyannis, R.C. Stevens, Z.-J. Liu, Crystal structure of the human cannabinoid receptor CB2, Cell 176 (3) (2019) 459-467, e413.

[26] L. Xia, H. de Vries, A.P. IJzerman, L.H. Heitman, Scintillation proximity assay 
(SPA) as a new approach to determine a ligand's kinetic profile. A case in point for the adenosine A 1 receptor, Purinergic Signal. 12 (1) (2016) 115-126.

[27] P.K. Smith, R.I. Krohn, G.T. Hermanson, A.K. Mallia, F.H. Gartner, M.D. Provenzano, E.K. Fujimoto, N.M. Goeke, B.J. Olson, D.C. Klenk, Measurement of protein using bicinchoninic acid, Anal. Biochem. 150 (1) (1985) $76-85$

[28] C. Yung-Chi, W.H. Prusoff, Relationship between the inhibition constant (KI) and the concentration of inhibitor which causes 50 per cent inhibition (I50) of an enzymatic reaction, Biochem. Pharmacol. 22 (23) (1973) 3099-3108.

[29] M. Soethoudt, M.W. Hoorens, W. Doelman, A. Martella, M. van der Stelt, L.H. Heitman, Structure-kinetic relationship studies of cannabinoid CB2 receptor agonists reveal substituent-specific lipophilic effects on residence time, Biochem. Pharmacol. 152 (2018) 129-142.

[30] Schrödinger, Schrödinger Release 2018-2, Schrödinger, New York, NY, 2018. 